\title{
Re-thinking Inclusion as a Discursive Practice: the Case of Hamas in the Israeli Discourse after 2006
}

\author{
Giovanni Pasquali \\ Global Development Institute, University of Manchester, UK
}

\begin{abstract}
The role of 'inclusiveness' in assessing the legitimacy of international negotiations assumes a central position in both theoretical and empirical studies of conflict-management and resolution. The focus of this scholarship, however, has been often restricted to the dynamics of physical participation and reciprocal communication without paying due attention to the discursive and linguistic level at which intersubjective understanding occurs. This article re-conceptualizes inclusiveness as a discursive practice and develops a multidimensional framework to assess its implications within the context of international conflict resolution. Building on previous work on linguistics and metaphor analysis, we develop four categories that are used to assess the level discursive inclusiveness of Hamas in the Israeli government's official statements after 2006 and preceding the 2010 peace talks: (i) war-like; (ii) criminal-like; (iii) evil-like; and (iv) adversary-like. Furthermore, we show how the circumstances in which statements were made (i.e. their field of action) further influence the metaphorical structure of the Israeli official discourse.
\end{abstract}

Index Terms-metaphor analysis, inclusiveness, legitimacy, Habermas, discourse, negotiation, IsraeliPalestinian conflict, Israel, Hamas

\section{INTRODUCTION}

International conflict resolution and dispute settlement often involve parties whose differences do not merely reside on their diverse policy standings, but encompass broader cultural issues (Gass and Seiter, 2008). Ascertaining the extent of these differences is pivotal in order to address the real causes of conflict and pave the ground for their resolution. This is all the more important considering recent failures of international negotiations that, despite bringing all disputing parties around the same table, have not managed to address the parties' reciprocal hatred and prevent the resumption of hostilities.

For instance, the peace talks that preceded the 2000 Arusha-Accords in the Burundi's civil conflict were dominated by a tense debate on whether inclusion of the disputing parties would have polarized the conflict and jeopardized the accords' outcome. In the end, the entrenched ethnic-nature of the dispute was converted into a political tool for the 'demonization of the other', degenerating in an uncontrollable process that spoiled the post-negotiation environment (McClintock and Nahimana, 2008). Similarly, despite an initial attempt to include disputing civil-society groups in 2002, the negotiations for the management of Sri Lanka civil confrontation under Norwegian mediation soon degenerated into an armed struggle with the government officially renouncing the ceasefire in 2008 (Wanis-St John and Kew, 2008, p.29). Again, as in the first case, direct participation and mutual communication failed to address the gap between political intentions and the parties' incompatible perception of each other.

Several efforts have been recently put forth within the domain of conflict-resolution and negotiation studies to tackle these complex issues. Central to the academic debate has been the identification of the conditions under which parties' inclusion is conducive to a legitimate and long-standing agreement. Particularly, drawing on Jürgen Habermas' theory of communicative action, some scholars have posited the existence of an uncoerced "ideal-speech situation" as the necessary precondition for the inclusion of all disputing parties and the legitimacy of final agreements (Head, 2008; Wehrenfennig, 2008). Nevertheless, not enough attention has been paid to "the telos of reaching understanding inherent in the structure of language" (Habermas, 1998, p.301). Namely, the discursive level at which intersubjective understanding is supposed to take place has been overlooked or assumed. In other words, the literature on negotiations studies and conflict resolution has often taken for granted the causal link between reciprocal communication and the formation of an inclusive ground for mutual understanding.

The main objective of this article is to challenge the ground of such assumption and analyse the how inclusiveness is constructed in then discourse underpinning the claims made by each disputing party. As the cases of Burundi and Sri Lanka illustrate, failing to acknowledge the discursive ground on which the relationship between unbiased communication and mutual understanding finally rests, leaves us with a deficient and ineffective comprehension of how legitimate agreements are achieved and substantiated.

The essay is structured in three main sections. The first one provides a critical appraisal of inclusiveness in its physical and communicative connotation. The second section examines the field of discursivity and the way it structures 
intersubjective relations by means of metaphorical articulations. The last section provides an empirical case-study focusing on Israel's perception of Hamas in the post-2006 scenario.

\section{PhysiCAL AND COMMUNICATIVE INCLUSIVENESS}

Juergen Haberms' theory of discourse ethics derives the legitimacy of a normative statement from the uncoerced and intersubjective recognition of the validity claims raised by its utterances (Habermas, 1990, p.58). In this sense, writes Habermas (Habermas, 1998, p.160), a "law can claim legitimacy only if all those possibly affected could consent to it after participating in a rational discourse". Legitimacy therefore draws on a principle of universalization, demanding the inclusion of every affected actor: "A norm is valid when the foreseeable consequences and side-effects of its general observance [...] could be jointly accepted by all concerned without coercion" (Flynn, 2003, p.434). Assuming a political connotation which entails the right to speak up without being internally or externally coerced, Habermas (1990, p.89) defines inclusion as the threefold right of every subject (1) "to take part in a discourse by introducing any proposal [...]", (2) "question any assertion whatever [...]", and, notably, (3) "[not being] coerced or prevented from exercising [one's own] rights of speaker". Drawing on Habermas (1990, p.92), this study defines this notion of inclusion as physical-inclusiveness.

Participation free from coercion (physical-inclusiveness) is not the only prerequisite for legitimacy. Actors should also be able to act communicatively, i.e. they shall engage in the redemption of their own statements with reasonable argumentations (Forchtner, 2010). Accordingly, drawing on the logic elicited by the "discourse-principle", Habermas defines communicative action the rational consensus amongst participants "brought about solely through the cogency of the arguments employed" (McCarthy, 1979, p.305). Rational argumentation relies on the speakers' perlocutionary will to reach understanding based on reasons that all participants together find acceptable (Habermas, 1999, p.119). Hence, it is possible to view consensus as implying a further level of locutionary inclusion - conceptualized here as communicative. In order for a legitimate outcome to take place, Habermas (1987, p.120) defines three claims of deliberative legitimacy: claim of truth, claim of rightness and claim of truthfulness. Failing to acknowledge these three claims implies the impossibility to reach understanding by means of communicative action.

Overall, drawing on Habermas' discourse ethics, it is therefore possible to delineate two mutually contusive layers of inclusion - physical and communicative - wherein the first is a necessary, though not sufficient, condition for the second. It is only as consequence of a shared "ethos of social integration" that the process of rational argumentation and the power of the better argument are put into a suitable context to emerge (Habermas et al., 1998, p.42). ${ }^{1}$

\section{DISCURSIVE INCLUSIVENESS: ANALYTICAL FRAMEWORK}

By postulating a transcendental ground for physical and communicative-inclusiveness, Habermas' discourse ethics universalizes the actors' agency through a process of rationalization that overlooks discourse as a potential source of inter-communitarian divergences.

\section{A. Beyond-Habermas: Internal and External Interpretative-communities}

An interpretative-community is defined as a social group whose validity claims are evaluated by means of specific values, assumptions, and "categories of understanding" embedded in the people's experience and cultural-heritage (Johnstone, 2004, p.189).

When a social actor is legitimated by her own internal community as a decision-maker, according to Habermas (2006, pp.132-135), she/he becomes a valid speaker for the external community. However, the latter's ability to validate their own (or someone else's) speech-acts depends strictly on their capacity to satisfy those requirements that legitimated them to occupy such position in the first place. In other words, democratically-appointed speakers are legitimised in their role by a "core" shared with the community they belong to - which constitutes the latter's identity and ground of ontological security (Habermas, 1988, pp.486-487).

In this peculiar environment, a problem emerges when the claims raised by the external interpretative-community are not consistent with those defining the identity of its internal counterparts. Thus, although speakers might be included and therefore granted with equal participation (physical-inclusion) and communicative rights (communicativeinclusion), a legitimate consensus cannot be reached to the extent that different interpretative-communities are ontologically defined in opposition to each other.

\section{B. Discursive Inclusiveness: Identity and the Concept of Stereotyped-image}

As Janice-Stein (2001, pp.190-191) points out, an interpretative-community engaged in inter-communitarian relations exists exclusively in virtue of its inter-subjectively constructed identity. Namely, its essence is a reflection of those "beliefs and scripts" through which the community itself is known by those outside of it. Yet, to the extent that a group's identity is defined in opposition to another group through stereotyped-images (i.e. a set of beliefs considered by the community as normatively characterizing "the other"), membership in this group will pass through a process of differentiation and antagonisation (Mitzen, 2006).

\footnotetext{
${ }^{1}$ This approach has been integrated into Critical Discourse Analysis (CDA) by the work of Forchtner (2010).
} 
In this respect, stereotypes tend to perpetuate themselves independently of any benevolent intentions of the counterpart, providing members with "ready-made responses" (Hopf, 2010). For this reason, once in place, stereotypes of antagonisation not only increase the level of certainty and self-confidence of the community's identity, but also stimulate a hostile response from the counterpart, generating a "cycle of reciprocal-behavior" that increases the level of path-dependency inherent in the stereotype (Stein, 2001, p.196).

While, group-leaders might be particularly enlightened to grasp and overcome stereotypes, it is hard to see how they could ever relinquish a constitutive trait of their identity without necessarily losing legitimacy within their interpretative-community. It is in this respect that, along with the concepts of physical- and communicativeinclusiveness, it is possible to identify a third level of inclusiveness rooted in the subjects' stereotyped-image of one another - i.e. we shall name this, discursive-inclusiveness.

\section{Discursive-inclusiveness as a Metaphorical Feature}

How can stereotyped-images be detected and classified in order to assess their level of discursive inclusiveness? Drawing on Laclau and Mouffe's (1985) discourse theory, this study posits articulation as the main ground for theoretical inquiry and language as the primary site of its manifestation.

According to Laclau, language does not represent a mere communicative device, but is instead a social phenomenon itself. It is through debate, disputes, and negotiations that structures of meanings are fixed and challenged. By engaging in communication people participate in a constant "strive" for the fixation of meaning (Jorgensen and Phillips, 2002, p.25). As in a sort of "fishing-net" that is constantly stretched and released, social actors create and re-create their social world by associating signs to different concepts in a process of articulation: "we will call articulation any practice establishing a relation among elements such that their identity is modified as a result of the articulatory-practice." (Laclau and Mouffe, 1985, p.105) In this respect "discourse is the structured totality resulting from the articulatory practice" - i.e. the fixation of elements into moments through a process of identity formation in which the meaning of each sign depends on its relation to the others ${ }^{2}$.

From an empirical perspective, articulation draws on metaphorical language according to which different elements are recontextualised within different discourses. Indeed, to the extent that the essence of a metaphor is "understanding and experiencing one kind of thing in terms of another" (Lakoff and Johnson, 2003, p.6), articulation is by definition a metaphorical activity. By fixing meanings in relation to nodal points, articulation operates metaphorically as it does not generate elements ex novo, but it (re)articulates them through the enactment of specific liaisons (Lakoff and Johnson, 2003, p.153; Torfing, 1999). Notably, as reported by Laclau and Mouffe (1985, pp.110-111), “[...] metaphor[s] are not forms of thought that add a second sense to a primary [...]; instead, they are part of the primary terrain itself in which the social is constituted." It is in this respect that "all discourse of fixation becomes metaphorical" and, it is in virtue of its metaphorical construction that fixation is never fully achieved and re-articulation is constantly brought into play. Hence, by re-articulating the structure of meaning embedded in several discursive-domains, metaphors intrinsically reshape people's thinking and acting (Black, 1993; Lakoff and Chilton, 1999, pp.54-55; Lakoff and Johnson, 2003, p.217).

Critically, the understanding of metaphor put forth in this article goes beyond the traditional realm of poetic and figurative language as semantic tools of embellishment (Lakoff, 1992, p.2); instead, metaphors become a fundamental element "of our ordinary, conventional way of conceptualizing the world" in terms of which we categorize our daily experience (Lakoff, 1992). Metaphors are cognitive frames, rather than direct comparisons: "a value system adopted to communicate linguistically a certain phenomenon." (Charteris-Black, 2005, p.18) This process is described also by Lakoff and Johnson (2003, pp.29) when referring to the metaphorical structure of discourses as constructed realities aimed at stabilizing the way of thinking of a certain community: "[o]ntological metaphors [...] are so natural and so pervasive in our thought that they are usually taken as self-evident, direct descriptions of social phenomena".

In this context, an analysis of the metaphors used by elites and governments' representatives in their statements sheds light on how discursive practices are constructed within an interpretative-community by means of constant "[re]articulation" (Jorgensen and Phillips, 2002, p.28). Accordingly, metaphor analysis embodies the third dimension of the Discourse-Historical-Approach put forth by Wodak and Reisigl (2009, p.93) - i.e. "Examining linguistic means and the specific, context-dependent linguistic realisations" - and, in this way, it helps unveiling the grounds on which the validity of a certain utterance is substantiated within an interpretative-community.

For the sake of clarity, metaphorical articulation by political leaders is not necessarily constitutive of a community's stereotyped images. Yet, a considerable amount of literature points to the critical role that government statements assume as instruments to forge public opinion (Cohen, 1995; Spencer, 2011, p.10). Governments' statements can inspire commitment and acquiescence among the public (Conger, 1991). Furthermore, their metaphorical construction can be instrumental in achieving a certain purposive aim (Charteris-Black, 2005; Mio et al., 2005, p.292). In fact, as we observed, effective persuasion needs to relay on a plethora of meaning shared by the public and their representatives (Jowett and O'Donnell, 1992, p.22). Even if we accept that the use of metaphorical articulations is independent of the manifestation of a group's identity, its analysis is still important to the extent that it is revealing of a specific rhetoric aimed at shaping, orienting and normalising discursive practices within a given community.

\footnotetext{
${ }^{2}$ A similar concept is expressed by Wodak-Reisigl (2009) in their definition of interdiscursivity and recontextualisation.
} 
To the extent that political speeches can be used as a persuasive tool of opinion-making, rather than just opinionstating, politicians may adopt specific metaphorical articulations with the aim of justifying certain policies in front of specific audiences. For instance, as reported by Kampf (2012), the political discourse of Palestinian recognition embedded in statements of sorrow, regret and apology has been subjected to strategic political calculations aimed at justifying conflicts or preventing undesirable international consequences by different Israeli leaders throughout the last decades. In a context where the process of identity formation is continuously renegotiated between victims and perpetrators, as well as government and opposition, it is important to avoid generalizing from results of a very limited sample to speak of broad characteristics of a diverse, multi-ethnic, multi-religious society such as Israel. Yet, despite not fully representative of their interpretative community, such official discursive events help to set the public agenda, increasing public awareness and understanding of some basic issues in the conflict (Kampf, 2012; Shamir et al., 1998).

\section{CASE Study: Hamas IN THE Post-2006 IsRaeli Political Discourse}

The aim of this section is to provide a case-study for the third level of inclusiveness developed in this essay - i.e. discursive inclusiveness. The focus is placed on the discursive patterns underpinning the exclusion of Hamas from the 2010 peace talks starting from January 2006, the year of Hamas' electoral victory in the elections for the PalestinianLegislative-Council.

\section{A. Hamas and the 2010 Peace Talks}

The Islamic-Resistance-Movement (Hamas) was created in 1987 by members of the Egypt's Muslim Brotherhood as a strategic action against the Israeli occupation of territories in the Gaza Strip, the West Bank and the Golan Heights. Its ultimate goal is the liberation of the historical Palestinian territory from the presence of Israel and the establishment of an independent Palestinian state under Islamic law. Furthermore, a second tenet of the Hamas' program is the "Islamization of society" - carried out through a profound concern for social justice, leadership accountability and democratic legitimation (Gunning, 2004, p.241; Mishal and Sela, 2006, pp.13-26).

Among the Western and Israeli public opinion, the optimism that the election of Mahmoud Abbas as president of the Palestinian Authority (PA) in 2005 generated in view of a future peace agreement in the Middle East was soon replaced by the emergence of a split inherent to the PA itself. The rivalry between Fatah and Hamas, the two main political powers in the Occupied-Palestinian-Territories, sharpened after Hamas' electoral success in January 2006 and the subsequent clash between the two factions, determining the emergence of two opposed Palestinian governments, one based in Gaza chaired by Hamas and the other in Ramallah (West-Bank) under the aegis of Fatah (Schanzer, 2008, pp.143-154). In this entangled situation, the Israeli government and the main international negotiators (i.e. the Quartet) ${ }^{3}$ positioned themselves on the side of Fatah, imposing harsh sanctions against the Hamas' jurisdiction in the Gaza Strip (Turner, 2009).

This reaction brought about the economic and political isolation of Hamas culminated with the movement's exclusion from the 2010 direct peace talks, wherein the mediation of the Obama administration recognized solely Fatah as representative of the PA. The reason for the exclusion of Hamas from the talks was the latter's refusal to embrace the three fundamental tenets expressed in the Quartet's official statement on 30th January 2006 following the elections, i.e. the recognition of Israel, the renounce to violence and the acceptance of the Oslo Accords of 1993.

This article explores the discursive patterns underpinning the exclusion of Hamas from the peace process within the Israeli field of discourse. As the research conducted by Mullin (2010) demonstrates, the refusal of Israel and the International Community to engage Hamas in the talks is to be seen more as the result of the "epistemological and ontological challenges" the Islamic Movement poses to the "dominant normative framework of the Western liberal peace", than as a mere consequence of Hamas' failure to comply with the Quartet's conditions. Mullin points to the ontological structure of the Israeli discourse as the main systemic tool through which thoughts and opinions are shaped. Nevertheless, as it is the case for other studies on the subject (Delacoura, 2006; Gunning, 2004; Toomey and Singleton, 2014), what seems to be generally omitted is a clear-cut distinction between the exclusion of Hamas from the peace talks (in the sense of its non-participation in the negotiation process) and the way in which the latter is and has been portrayed in the Israeli official discourse.

\section{B. Sampling}

The units of analysis consist of key-speeches by Israeli Prime Ministers (PMs) and Ministers of Foreign Affairs (MFAs) between 2006 - year of the election for the Palestinian Legislative Council - and September 2010 - official starting date of the direct peace talks mediated by the Obama administration in Washington. Specifically, this study concentrates on 40 speeches selected from 69 speeches of PMs and 124 of MFAs. The selection was done on speeches where Hamas is mentioned in relation to a political context linked to the process of peace settlement; this includes asoects of territory boundaries, peace talks (e.g. negotiations), elections, diplomatic relations, administrative rule over the territory and internal or external governance.

\footnotetext{
${ }^{3}$ The Quartet, composed by the UN, the US, Russia and the EU, was constituted during a meeting between the US Secretary of State, the representatives of the UN, EU and Russia in Madrid in 2002.
} 
This study adopts three main levels of sampling: time frame, official speeches and political relevance of the speeches.

With regard to the time frame, we concentrate on the post-2006 period. Indeed, as Habermas (1999, p.127) asserts, only an institutionalized procedure that guarantees the participation of all citizens to the deliberative process can guarantee the legitimacy of the final outcome. In light of the widespread international recognition for the fair conditions in which the 2006 electoral turnout took place (Quartet, 2006), it appears congruent to identify Hamas' success as a source of international legitimation.

Concerning the subjects whose speeches are analysed, namely the Israeli PM and MFA, the choice has been made because of the official position held by these actors. Whereas a more encompassing research should include sources from different political perspectives within Israel such as press articles and opposition keynotes, the analysis of official government's speeches allows us to draw some initial conclusion on patterns of discursive inclusiveness put forth by the Israeli administration. These are by no means exhausting and, as specified in section 3.3, no claim is made to imply that such statements mirror the Israeli people's view with respect to Hamas.

Finally, the third level of selection is the political relevance of the speeches. The units of analysis are chosen among issues concerning the peace process. This criterion is evaluated based on the title and context in which the speeches were given, granting privilege to those relating to an international environment linked to the Israeli position in the conflict.

\section{Data Analysis}

The case-study concentrates on the operationalisation of the third level of inclusiveness discussed in section 3 - i.e. discursive-inclusiveness. In a previous study, the author has defined the analytical categories to operationalise the first two stages of inclusiveness for the same case-study (Pasquali, 2012).

\section{Operationalizing Discursive Inclusiveness}

Section 3.1 linked the concept of discursive inclusiveness to that of identity and stereotyped images. Drawing on previous studies adopting metaphor analysis (Hülsse et al., 2008; Spencer, 2011), this section introduces four metaphorical images used to (re)articulate stereotypes about "the other" as part of a community's identity.

The categorisation of metaphors has been operated on the base of two main principles. Firstly, in order to determine whether a word is ascribable to a certain metaphorical structure, the current study makes use of dictionary definitions. As Hülsse (2006) points out, it is in dictionaries that the common knowledge concerning a particular phenomenon is normally stored. This operation allows the author to disclose the semantic relations between the two terms (see next sections for semantic-groups and examples).

Here, however, a problem emerges with regard to the persuasive use of speeches pinpointed in the previous paragraphs. Several authors have shown how politicians borrow discourses external to their interpretative-community to legitimise specific actions and policies (Graham et al., 2004; Jayyusi, 2012). This has also been the case in the IsraelHamas relations wherein the Israeli government appropriated the discourse on "the war on terror" to legitimise and normalise the use of warfare (Toomey and Singleton 2014). According to Chilton and Ilyin (1993), an interplay between actors with different identities requires an analysis of the circumstances in which speech-acts occur. In order to account for the contextual aspect, the analysis of metaphor proposed here is accompanied by an assessment of the "field of action" surrounding the speech (Wodak and Reisigl, 2009, pp.90-91).

Moreover, metaphors cannot be interpreted without accounting for a subjective element. As Spencer (2011, p.9) points out, identifying expressions does always entail a measure of subjectivity and randomness. Similarly, as stressed by Cameron (2007, p.206), a metaphor can always fit into more than one specific category because of the indeterminacy inherent in the human process of "meaning making". In order to reduce the subjectivity inherent in the process of categorization, this study implemented a double-check procedure with the support of another two scholars (Johnson, 1997, p.287).

In light of this fundamental premise, it is now possible to define the four categories used in the analysis.

\section{War-like metaphor}

The use of war metaphors in reference to Hamas implies a process of mapping knowledge about war on the more abstract ontology of Hamas.

Attaching military metaphors to a particular idea renders the latter more understandable to the public inasmuch as it depicts a certain entity in terms of a rational military organization. Accordingly, the use of warlike metaphors entails the constitution of Hamas as an external enemy waging war against Israel - where war refers to a confrontation between alike-units induced by a state of competition, conflict or hostility.

Military reaction is the common denominator of war, as both parties are ready to respond military to every attack originating from the other side. However, it is exactly by fighting against each other on a like-base that both parties automatically legitimize their opponent. As Hülsse et al. (2008, p.585) acknowledge, a war situation describes a relation of parity between state-like entities wherein utterances such as "we can still maneuver" (Olmert 14/02/2006), "during a war these kind of mistakes can happen" (Livni 20/11/2006) and, again, "Hamas has now begun to be more like a small army and less a terrorist organization" (Livni 05/03/2008), construct a relation of enmity in which not only the use of one's own military force against the other becomes a logical consequence, but also negotiation and reconciliation constitute possible strategies not excluded a-priori. Table-1 in the appendix contains a list of metaphors falling under 
this category.

\section{Hamas as criminal}

In contrast to the war-like metaphor, this second category entails the re-articulation of Hamas' in terms related to the semantic field of criminality. Accordingly, instead of referring to the Islamic movement as an "enemy" (Livni 10/02/2008) or a "small army" (04/03/2008) against whom waging war, the Israeli leadership identifies the latter as a "murder" (Olmert 23/10/2007), a "gang" or a group of "cronies" (Olmert 17/07/2006) committing illegal actions - such as "smuggling" (Livni 01/10/2007) and "kidnapping" (Netanyahu 14/06/2009) - that need to be "sanctioned" (Livni 04/07/2007).

The relation between the speaking subject and the object turns the latter into an "enemy within", i.e. a member of the former's community, whose criminal behaviour needs to be punished. Contrary to the war-like metaphor, by referring to Hamas as a criminal, the Israeli leadership establishes a hierarchical relation in which the Islamic movement does not represent a "like-unit", but rather an inferior and illegitimate actor (Spencer, 2011). In this sense, the shift of structural metaphors from war enemy to 'criminal' determines the delegitimation of Hamas as an "outlaw" that cannot be circumscribed but rests, instead, within Israel's society itself.

Accordingly, if, on the one hand, a war enemy is a like-unit whose "right to exist" is normally acknowledged by the opposite side, on the other, a criminal is always illegitimate: not only he refuses to recognize the same rules of the game, but he deliberately breaks these rules calling for state policing and juridical countermeasures aimed at achieving "deterrence" (Livni 02/02/2009; 11/01/2009). In this case, the latter's behaviour is usually considered as "non-rational" (Liberman 28/04/2009) and unacceptable according to the moral standards shared by a community. Table-1 in the appendix contains a list of metaphors falling under this category.

\section{Universal evil-like metaphor}

The use of a universal evil-like metaphor implies the re-articulation of the other's attributes in terms of those typical of an absolute threat whose mere existence is viewed as profoundly immoral and harmful for the social body.

In this respect, the construction of the other's identity as evil excludes from the beginning every discussion on the reasons guiding the latter's actions (Spencer, 2011). Indeed, to the extent that the other is classified as morally evil, its political aims are automatically delegitimized and the motives behind its behavior ascribed as an unbearable "threat" bearing exclusively to "brutal actions" (Olmert 15/02/2009). Accordingly, such metaphorical construction implies an extreme form of polarization of the relations between the two actors: on one side the 'good guys' and, on the other, the 'badies'.

By means of the evil metaphor every form of negotiation or compromise becomes not only impossible but also unthinkable; indeed, "no deal can be done with the devil". The only solution, in this sense, is to fight and "eradicate the obstacle" (Olmert 26/03/2008) along with its "extreme ideology" (Livni 01/10/2007). Table-1 in the appendix contains a list of metaphors falling under this category.

\section{Political adversary-like metaphor}

The structural metaphors described so far have been ordered in terms of their reconciliatory nature. If in a war-like context the room for reconciliation is tight but present, the same does not apply to the two other categories. Indeed, while, on the one hand, the exclusion of negotiation generated by criminal metaphors still allows for redemption by means of punishment and deterrence, on the other hand, the adoption of universal-evil utterances prevents every concrete possibility for reconciliation.

Chantal Mouffe (2005) acknowledges a separation between antagonism in war-like terms and an 'agonistic struggle' within a shared political arena. While, on the one hand, antagonism refers to a dispute of enemies aiming at each other's destruction; agonism, on the other, implies a relation among adversaries who "respect the right of [their] opponent to defend his or her point of view" (Worsham and Olson, 1999). In this sense, an adversary differs from an enemy to the extent that his/her demands are recognized as legitimate within an inclusive democratic discourse (Mouffe, 2005, p.50); that is, an adversary is "somebody whose ideas we combat but whose right to defend those ideas we do not put into question.” (Ruitenberg, 2009)

The category of 'war-like enemy' does not disappear tout-court but remains present to indicate "those who do not accept the democratic 'rules of the game' and who thereby exclude themselves from the political community" (Worsham and Olson, 1999). The agonistic dimension coexists next to its antagonistic counterpart as a "struggle between opposing hegemonic projects" that, by means of democratic institutions and practices, reduces the probability of a violent outcome in the political debate (Mouffe, 2005, p.21). ${ }^{4}$

Examples of political-adversary metaphors are reported in table-1. It is important to notice here that, whenever Hamas is linked to a political adversary terminology, this is often done in a negative context aimed at denying rather than recognizing the role of Hamas as legitimate political player.

$\underline{\text { 5. Field of action }}$

According to Wodak and Resigl (2009), interdiscursivity implies that discourses are often linked to each other in various ways. As stressed in the previous sections, this is particularly relevant to the extent that metaphorical articulations can be used as means of persuasion that depend more on the specific context surrounding the speech rather

\footnotetext{
${ }^{4}$ Mouffe's (2000) debate on the concept of agonism and adversary is embedded in her critique of Habermas model of deliberative democracy.
} 
than on shared values between the speaker and the public (Charteris-Black, 2005; Kampf, 2012). For instance, several studies have focused on the (re)contextualisazion and appropriation of the post 9/11 discourse of the "war on terror" within local arenas such as the post conflict political discourse in Serbia (Erjavec and Volcic 2007), the (re)construction of the Muslim-other within the Western society (Jayyusi 2012), and the relationship between the Sri Lanka Government and the Tamil Tigers (Toomey and Singleton, 2014).

In this context, Wodak and Resigl (2009, pp.90-91) use the term "field of action" to indicate a segment of social reality that constitutes the frame of a discourse: "a discourse about a specific topic can find its starting point within one field of action and proceed through another one." Yet, whereas the link between discourses external and internal to the Israeli interpretative-community, as well as differences within the community itself (e.g. different ethnic and religious groups, as well as political parties...), is acknowledged as a limitation in the study, it is still possible to contextualise the analysed speeches in relation to their audience and circumstances. This categorization should unveil some preliminary insights on whether the metaphorical structure of discourse is influenced by its context. For this purpose, each of the 40 speeches has been coded using three dummy variables depending on whether: (i) it was addressed to an international or local-audience; (ii) it was held during a period of national election or not; and (iii) it was given during an ongoing conflict or not $^{5}-$ refer to table-2 in the appendix.

\section{E. Results}

As presented in table-2 in the appendix, the metaphor "Hamas as war" is preeminent. This trend suggests that, whilst Hamas' exclusion from the peace process is certainly a consequence of its failure in complying with the Quartet's conditions, its inclusiveness in the Israeli official discourse displays an ontological challenge to Israel's identity. The extent to which the metaphorical structure of the discourse is a cause or a consequence Hamas' non-compliance with the Quartet's conditions however remains questionable.

Yet, the pre-eminence of the war-enemy metaphor should not be regarded as a way-out from a conflicting situation. The cornerstone of the antagonist relationship between war enemies is a mutual and shared desire for the other's final capitulation and destruction. In this sense, despite the status of parity enjoyed by the parts, a war-like approach freezes (although it does not erase) the chances for an unconstrained and inclusive dialogue. As Mouffe (2005) points out, this situation can be overcome only through a 'field of competitiveness' in which the right of 'the other' to defend its own view is guaranteed by the democratic structure in which the discourse between the parties is embedded. Now, as table-2 illustrates, this dynamic is inconsistent with the position taken by the Israeli leadership since 2006. In fact, to the extent that political-adversary metaphors are used, they are always placed within a negative context where the adversary role is directly denied rather than asserted.

Looking at the data in the appendix, a shift in the Israeli discourse on Hamas seems to have occurred at the end of 2008 in conjunction with Israel's execution of the Operation Cast-Lead in Gaza. During this period (December 2008January 2009) the number of references to Hamas has drastically shifted from a majority of universal evil and criminal metaphors to a significant increment in the number of war-like related terms. This trend, observable in table-2, becomes particularly striking in the case of FM Livni, whose number of analysed speeches constitutes more 50\% of the total units of analysis. The ratio between war enemy and universal evil metaphors raised from 1.2 (34/28) to 3 (77/26) between 2008 and 2009. One year before, during the internecine clashes between Fatah and Hamas, these ratios were substantially inverse and the number of universal evil references outperformed alone the number of war-like related terms.

These results are in accordance with what asserted in section 3. Indeed, after the 2006 elections, the first objective of Israel was to delegitimize Hamas by offering exclusive support to the latter's political opponent Fatah. As it emerges, this process of delegitimation also assumed a discursive connotation in which the identification of Hamas as universal evil might have fostered the exclusion of the latter to the advantage its political counterpart Fatah. Likewise, the sudden switch at the end of 2008 - i.e. from a criminal/universal evil structural metaphor to a war one - might to relate to the Israeli government need to justify Operation Cast-Lead as a legitimate act of warfare in front of the national and international public.

Finally, the analysis of the field of action in Table-2 displays a significant relationship between the field of action surrounding a speech-act and its metaphorical structure. Specifically, the use of paired t-tests on the 40 speeches evidences how war-like metaphors are more likely to be used during both election and conflict periods, ${ }^{6}$ although the concurrence of the 2009 election with the Operation Cast-Lead might indicate an overlapping between the two groups' significant outcome. Similarly, criminal-like metaphors appear to be significantly more recurring during conflict periods. ${ }^{7}$ This patterns may suggest that persuasive speeches are adopted by leaders to justify a certain course of actions (Charteris-Black, 2005), rather than being reflective of an interpretative-community. In this sense, the numerous references contained in the analysed speeches depicting the Cast-Lead operation as a local act of an international "war on terror" bring further support to this consideration (Livni 29/12/2008; 03/01/2009; 05/01/2009; 11/01/2009;

\footnotetext{
5 "Electoral" refers to whether the speech was given in a time approaching national elections, whereas "conflict" refers to whether there was an upcoming, ongoing or recently concluded military operation in Gaza by the IDF.

${ }^{6} 0.01$ significance-level.

${ }^{7} 0.05$ significance-level.
} 
$15 / 01 / 2009 ; 21 / 01 / 2009)$ and highlight the need for further research on the circumstances underpinning the (re)contextualisation of external discourses within localised contexts (Erjavec and Volcic, 2007; Jayyusi, 2012; Toomey and Singleton, 2014).

\section{CONCLUSION}

Drawing on Habermas' theory of discourse ethics, the object of this essay has been to identify, classify, and operationalise different categories of inclusiveness within the context of international negotiation and conflictresolution.

The article conceptualised three degrees of inclusiveness for the achievement of legitimate agreements. Whereas the first two levels - i.e. physical and communicative - constitute the core of the Habermasian theory and have so far been applied in several studies, less attention has been paid to the stereotyped-images constituting one community's identity and defining its intersubjective relation to other external communities. In this respect, section 3 has introduced the concept of discursive-inclusiveness as the perceived image that an interpretative-community has of "the other". As we argued, it is possible to provide some insights on the degree of discursive-inclusiveness of a community by critically evaluating the articulation of its official statements, with a focus on the metaphorical language adopted by governments and other official institutions. This article empirically evaluated this approach through an analysis of the Israeli governments' official speeches relating to Hamas in the post-2006 scenario. Results have been summarized in section 4.5 .

Critically, official statements often imply an element of persuasiveness aimed at building rather than reflecting a community's identity. For this purpose, acknowledging the influence of external circumstances (referred here as the field of action) on official statements is pivotal. For instance, we showed how the use of a 'war-like' metaphor by Israeli official may have been instrumental in justifying the Operation Cast-Lead under the tenet of the "war on terror".

Several aspects are still open to further research. Namely, the extent to which different forms of inclusiveness (physical, communicative, and discursive) are essential to the achievement of long-standing agreements remains questionable. In this respect, future work should focus on the relation between international negotiations, identity formation and the metaphorical structure of discourse. Furthermore, scholars need to shed light on the link between broader international shifts and the (re)contextalisation of discourses such as the "war on terror" and the "axis of evil" not only on the political justification of repressive actions (Erjavec and Volcic, 2007; Toomey and Singleton, 2014), but also as a persuasive instrument of identity formation (Wodak and Reisigl, 2009). Finally, as we observed, official statements often reflect a number of different institutions and audiences that co-exist within a community (e.g. political parties, civil society organizations, religious groups...). It is therefore critical to shed further light on how these diverse internal institutions interact to shape the government's official discourse in relation to other external communities. 
APPENDIX

TABLE-1

List OF METAPHORICAL THEMES By CATEgORIES (EXAMPLeS)

\begin{tabular}{|l|}
\hline War \\
"Abu Mazen sought to hold these \\
elections with the participation of the \\
Hamas, claiming that he did not have the \\
legitimacy to fight the terror \\
organizations and to disarm them. [...]" \\
(Livni $26 / 02 / 2006)$ \\
"On both fronts we are exercising self- \\
defense in the most basic and essential \\
sense" (Olmert $17 / 07 / 2006)$ \\
"During a war these kind of mistakes \\
can happen" \\
(Livni $20 / 11 / 2006)$ \\
"This in order to give those Palestinians \\
who, I believe, want to live in peace as \\
well, the opportunity to understand that \\
Hamas cannot deliver..." \\
(Livni $17 / 01 / 2007)$ \\
"I do think there are other measures, \\
beyond dramatic military steps that we \\
can take" \\
(Livni $01 / 10 / 2007)$ \\
"Hamas is the enemy of Israel, Hamas is \\
the enemy of the Palestinians and Hamas \\
is the enemy of the free world that is \\
seeking peace" \\
(Livni $10 / 02 / 2008)$ \\
"We can see the smuggling of weapons \\
and the buildup of a small army by \\
Hamas within the Gaza Strip. [...] With \\
this process of buildup in Hamas, we are \\
now facing a small army... [...] To work \\
with the moderates to try and find a \\
peace treaty while fighting Hamas. [...] \\
Even though we are on the front lines" \\
(Livni $04 / 03 / 2008)$ \\
\hline
\end{tabular}

\section{Criminal}

"The region in which we live is threatened by these murderous terror groups. Israel will not be held hostage - not by terror gangs..."

(Olmert 17/07/2006)

"There is no comparison in any kind of legal system which is based on the values of society between a murderer and between somebody who is killed by mistake. [...]"

(Livni 20/11/2006)

"Gaza falling into Hamas' hands... [...] One that is not run by Hamas and is not a Hamas government in the guise of a coalition government..."

(Livni 18/06/2007)

"[Hamas is] suffocating the voices of hope and co-existence wherever it can. [...] I believe a price has to be paid for the daily attacks on Israel from Gaza."

(Livni 01/10/2007)

"Now clearly, this border is being used - abused by-Hamas in order to smuggle weapons into the Gaza Strip and this is something that we cannot afford."

(Livni 05/03/2008)

"Iran's fingerprints are evident in almost every terrorist organization across the Middle East, from Hamas and Islamic Jihad in the Gaza Strip. [...] Tens of thousands of innocent Israeli citizens live daily in constant fear and anxiety, under a barrage of missiles, serving as pawns in a cruel, malicious game of roulette played by the Hamas and its cronies in the Gaza Strip."

(Olmert 04/06/2008)

And our ability to maintain this boycott [punishment] for a few years already."

'The idea of war is not part of our vision but, yes, we need to protect our citizens and this is the reason that when Israel is under attack we need to react"

(Livni 12/03/2008)

"The entirety of this tremendous missiles store is aimed at the State of Israel's civilian home front. [...]"

(Olmert 18/12/2008)

"The road to peace passes through the war on terror, extremism, hate and incitement, which means a war against Hamas and those like Hamas"

(Livni 29/12/2008)

"While targeting the Hamas, we try to avoid civil casualties, but unfortunately, during this kind of war sometimes... [...] Not to expect Israel to find a way to reach a treaty with the Hamas. This is not going to happen"

(Livni 08/01/2009)

"So we started this operation and this was the military objective of the operation ..." (Livni 11/01/2009)

"Hamas was badly stricken, both in terms of its military capabilities and in the infrastructure of its regime. [...] It placed its military system in crowded residential neighborhoods... [...] If our enemies decide that the blows they have already suffered are not enough..."

(Olmert 17/01/2009)

"Third, complete, total, ceasefire and any hostile activity by the Hamas from Gaza. [...]."

(Olmert 15/02/2009)

"Hamas, which is holding the population hostage. [...] The thin line between what is allowed and what is forbidden must not be crossed - between legitimate and illegitimate, between right and wrong"

(Livni 29/12/2008)

"Hamas took the Palestinians in the Gaza Strip hostage. [...] They are abusing the willingness of Israel to work and to provide an answer the humanitarian needs. [...]"

(Livni 08/01/2009)

"One is impairing the other side's ability; the other is impairing motivation. [...]"

(Livni 11/01/2009)

"There is a huge difference between a murderer and somebody who kills by mistake. And this is the moral distinction between Hamas, who keeps these civilians hostage, and our soldiers" (Livni 21/01/2009)

"We are acting against Hamas, since this is a terrorist organization, which, in a way, is abusing the fact that it controls the civilian population in order to target Israel..."

"Murderers of Israeli citizens. [...] Threatened

by murderous terrorist organizations (in reference to Hamas)..."

(Olmert 17/03/2009)

"This cruel, murderous terror organization that has not allowed the Red Cross to visit Gilad Shalit even once during his years of captivity. [...] The second principle is to prevent the release of mass murderers. [...] These are archmurderers who planned and carried out the most shocking and horrendous terror attacks, in

\section{Universal evil}

"If Hamas decides to continue its wild

between legitimate and illegitimate,

(Livni 03/03/2009) which an extremely large number of innocent Israeli citizens were murdered"

(Netanyahu 01/07/2010)
"The world is also aware of the fact that it is undesirable to have a Palestinian Authority with two heads, the good guy and the bad guy"

(Livni 26/02/2006)

"Remove this threat from the Middle

East. [...] Will we consent to living under the threat of this Axis of Evil?" (Olmert 17/07/2006)

"We all know that the Gaza Strip is dependent on Israel's goodwill in several things. [...] The ideology of Hamas is an extreme ideology. There is no hope for the Palestinians and for Israel with Hamas on board"

(Livni 01/10/2007) terrorist attacks. [...] The cruel reality created by Hamas..."

(Olmert 17/01/2008)

"Hamas is an obstacle"

(Olmert 26/03/2008)

"The existence of an axis [of evill ${ }^{1}$ stretching from Tehran through Damascus to the Hizbullah in Lebanon and the Hamas in the Gaza Strip'

(Olmert 18/12/2008)

"Hamas is an extremist Islamic organization. It lives off fear and hate [...]. The road to peace passes through the war on terror, extremism, hate and incitement. [...] The thin line

between what is allowed and what is forbidden must not be crossed.

Political adversary

In fact for the first time Hamas eader, Haniyeh, said that he is willing to give up his post as a prime minister in an understanding that he needs and the Hamas needs to win legitimacy from the international community"

(Livni 20/11/2006)

"[...] the opportunity to understand that Hamas cannot deliver - not in economic terms, nor in political terms"

Livni (17/01/2007)

"Whoever voted for Hamas, whoever lives in Gaza and warmly accepted these terrorists, will now find themselves in a situation where their leadership and government do not receive legitimacy, money or support from the international community and have no political horizon to offer them"

(Livni 18/06/2007)

"The Hamas is not considered to be a good partner..."

(Livni 04/07/2007)

"It gives Hamas the keys to the negotiations. And I hope that this was the last time that happens"

(Livni 12/03/2008)

"Because I'm not going into a room with Hamas; I don't want to give them legitimacy [...] To legitimize Hamas is not in Israel's interest. ." (Livni 03/01/2009) between right and wrong"

(Livni 29/12/2008)

"I would say that the Gaza Strip controlled by Hamas is a burden not only to Israel but to the Palestinians themselves. [...] It is a conflict between moderates and extremists" (Livni 10/01/2009)

"It represents an ideology of hatred and what they call "resistance." So hope for Palestinians, and Israelis as well, lies in the peace process track with the legitimate Palestinian government while all of us need to work against extremism and the kind of terror being used by Hamas"

(Livni 21/01/2009)

These brutal terrorists in Gaza ... [...] Arab leaders are threatened by the extremity of these organizations..." (Olmert 15/02/2009)

Hamas represents the extremists in the region. They are trying to act according to their own ideology of resistance, of acting against anyone who lives in the region"

(Livni 03/03/2009)

"It was not independence, and not because they believe in Hamas's radical ideology... [...] Today you have the influence of some nonrational players... (Referring to Hamas)"

(Lberman 28/04/2009)
Damascus surely understand"

(Livni 11/01/2009)

"Hamas cannot be legitimized unless it accepts the international requirements"

(Livni 15/01/2009)

"The international community decided, after Hamas won the elections, that the only way to give egitimacy to them is if they accept he international requirements"

(Livni 21/01/2009)

"There is another thing which is important for us, and it is related to the crossings - not to the humanitarian aid, but to something that Hamas wants to happen from its own political perspective"

(Livni 03/03/2009)

"Hamas cannot be a partner to any discussions, any talks or any process"

(Liberman 28/04/2009)

"Both of these organizations, whose proclaimed primary purpose is the destruction of the State of Israel, cannot be legitimate partners in any negotiations"

(Liberman 03/06/2009)

"I think that Hamas is making a mistake but the ball is in their court" (Netanyahu 01/07/2010) 
TABLE-2:

EXTENDED MATRIX OF METAPHOR AND FIELD OF ACTION ANALYSIS.

Int=1 If The Context Of The Speech Is International And 0 If Local; Election=1 If The Speech Was Held During Election-Time; Conflict=1 If The Speech Was Held In Conflict Time. The Numbers Reported In The Metaphor Columns Refer To The How Many Times A Metaphorical Theme Was Used.

\begin{tabular}{|c|c|c|c|c|c|c|c|c|}
\hline \multirow[b]{2}{*}{ Speaker } & \multirow[b]{2}{*}{ Date } & \multicolumn{3}{|c|}{ CONTEXT } & \multicolumn{4}{|c|}{ METAPHOR } \\
\hline & & Int. & Election & Conflict & WAR & CRIMINAL & EVIL & ADVERS. \\
\hline Olmert & $14 / 02 / 2006$ & 1 & 1 & 0 & 5 & 0 & 0 & 1 \\
\hline Olmert & $17 / 07 / 2006$ & 0 & 0 & 1 & 1 & 4 & 2 & 0 \\
\hline Olmert & $13 / 03 / 2007$ & 1 & 0 & 0 & 0 & 3 & 0 & 2 \\
\hline Olmert & $23 / 10 / 2007$ & 1 & 0 & 0 & 0 & 1 & 0 & 0 \\
\hline Olmert & $17 / 02 / 2008$ & 0 & 0 & 1 & 1 & 0 & 0 & 0 \\
\hline Olmert & $26 / 03 / 2008$ & 1 & 0 & 1 & 2 & 1 & 1 & 1 \\
\hline Olmert & $04 / 06 / 2008$ & 1 & 0 & 0 & 0 & 4 & 0 & 0 \\
\hline Olmert & $18 / 12 / 2008$ & 0 & 1 & 1 & 2 & 0 & 2 & 0 \\
\hline Olmert & $17 / 01 / 2009$ & 0 & 1 & 1 & 3 & 4 & 2 & 1 \\
\hline Olmert & $15 / 02 / 2009$ & 1 & 1 & 1 & 3 & 4 & 3 & 0 \\
\hline Olmert & $17 / 03 / 2009$ & 0 & 1 & 1 & 0 & 2 & 0 & 0 \\
\hline Netanyahu & $14 / 06 / 2009$ & 0 & 0 & 0 & 1 & 1 & 1 & 0 \\
\hline Netanyahu & $15 / 11 / 2009$ & 0 & 0 & 0 & 2 & 0 & 0 & 0 \\
\hline Netanyahu & $01 / 07 / 2010$ & 1 & 0 & 1 & 0 & 8 & 3 & 1 \\
\hline Netanyahu & $08 / 07 / 2010$ & 1 & 0 & 0 & 0 & 2 & 0 & 0 \\
\hline Netanyahu & $20 / 09 / 2010$ & 1 & 0 & 0 & 1 & 0 & 0 & 0 \\
\hline Livni & $26 / 02 / 2006$ & 1 & 1 & 0 & 2 & 0 & 1 & 0 \\
\hline Livni & $20 / 11 / 2006$ & 1 & 0 & 1 & 2 & 2 & 7 & 2 \\
\hline Livni & $17 / 01 / 2007$ & 1 & 0 & 0 & 3 & 2 & 8 & 1 \\
\hline Livni & $18 / 06 / 2007$ & 1 & 0 & 0 & 0 & 2 & 5 & 2 \\
\hline Livni & $04 / 07 / 2007$ & 1 & 0 & 0 & 3 & 2 & 2 & 1 \\
\hline Livni & $01 / 10 / 2007$ & 1 & 0 & 0 & 4 & 3 & 8 & 0 \\
\hline Livni & $22 / 01 / 2008$ & 0 & 0 & 1 & 1 & 0 & 4 & 1 \\
\hline Livni & $10 / 02 / 2008$ & 0 & 0 & 1 & 4 & 0 & 3 & 0 \\
\hline Livni & $04 / 03 / 2008$ & 1 & 0 & 1 & 5 & 4 & 5 & 0 \\
\hline Livni & $05 / 03 / 2008$ & 1 & 0 & 1 & 3 & 3 & 2 & 0 \\
\hline Livni & $12 / 03 / 2008$ & 1 & 0 & 1 & 8 & 0 & 2 & 1 \\
\hline Livni & $18 / 12 / 2008$ & 0 & 1 & 1 & 2 & 4 & 3 & 0 \\
\hline Livni & $29 / 12 / 2008$ & 0 & 1 & 1 & 6 & 8 & 6 & 0 \\
\hline Livni & $03 / 01 / 2009$ & 0 & 1 & 1 & 5 & 1 & 0 & 4 \\
\hline Livni & 05/01/2009 & 1 & 1 & 1 & 16 & 1 & 1 & 1 \\
\hline Livni & $08 / 01 / 2009$ & 1 & 1 & 1 & 9 & 3 & 0 & 1 \\
\hline Livni & $10 / 01 / 2009$ & 1 & 1 & 1 & 5 & 2 & 3 & 0 \\
\hline Livni & $11 / 01 / 2009$ & 1 & 1 & 1 & 10 & 8 & 0 & 3 \\
\hline Livni & $15 / 01 / 2009$ & 1 & 1 & 1 & 3 & 5 & 3 & 1 \\
\hline Livni & $21 / 01 / 2009$ & 1 & 1 & 1 & 9 & 9 & 3 & 1 \\
\hline Livni & $02 / 02 / 2009$ & 1 & 1 & 1 & 6 & 2 & 4 & 1 \\
\hline Livni & $03 / 03 / 2009$ & 1 & 1 & 0 & 2 & 3 & 2 & 2 \\
\hline Liberman & $28 / 04 / 2009$ & 0 & 0 & 0 & 3 & 2 & 3 & 1 \\
\hline Liberman & $03 / 06 / 2009$ & 1 & 0 & 0 & 0 & 0 & 1 & 2 \\
\hline
\end{tabular}




\section{REFERENCES}

[1] Black, M. (1993). More about Metaphor. In Ortony, A. (ed.), Metaphor and Thought. New York: Cambridge University Press, $19-41$.

[2] Cameron, L. J. (2007). Patterns of Metaphor Use in Reconciliation Talk. Discourse \& Society 18.2, 197-222.

[3] Charteris-Black, J. (2005). Politicians and Rhetoric: The Persuasive Power of Metaphor. London: Palgrave Macmillan.

[4] Chilton, P. \& M. Ilyin. (1993). Metaphor in Political Discourse: The Case of the 'Common European House'. Discourse \& Society $4.1,7-31$.

[5] Cohen, J. E. (1995). Presidential Rhetoric and the Public Agenda. Am. J. Pol. Sci. 39.1, 87-107.

[6] Conger, J. A. (1991). Inspiring Others: The Language of Leadership. Academy of Management Executive 5.1, 31-45.

[7] Delacoura, K. (2006). Islamist Terrorism and the Middle East Democratic Deficit: Political Exclusion, Repression and the Causes of Extremism. Democratization 13.3, 508-25.

[8] Erjavec, K. \& Z. Volcic. (2007). 'War on Terrorism' as a Discursive Battleground: Serbian Recontextualization of G.W. Bush's Discourse. Discourse and Society 18.2, 123-37.

[9] Flynn, J. (2003). Habermas on Human Rights: Law, Morality, and Intercultural Dialogue. Social Theory and Practice 29.3, 431-457.

[10] Forchtner, B. (2010). Jürgen Habermas' Language-Philosophy and the Critical Study of Language. Critical Approaches to Discourse Analysis across Disciplines 4.1, 18-37.

[11] Gass, R. \& J. Seiter. (2008). Credibility and Public Diplomacy. In Snow, N. \& P. Taylor (eds.), Routledge Handbook of Public Diplomacy. New York: Routledge, 154-165.

[12] Gavriely-Nuri, D. (2008). The 'Metaphorical Annihilation' of the Second Lebanon War (2006) from the Israeli Political Discourse. Discourse \& Society 19.1, 5-20.

[13] Graham, P., T. Keenan, \& A. Dowd. (2004). A Call to Arms at the End of History: A Discourse-Historical Analysis of George W. Bush's Declaration of War on Terror. Discourse \& Society 15.2, 199-221.

[14] Gunning, J. (2004). Peace with Hamas? The Transforming Potential of Political Participation. International Affairs 80.2, 233255.

[15] Habermas, J. (1987). The Theory of Communicative Action (Vol. 2). Lifeworld and System: A Critique of Functionalist Reason. Boston: Beacon Press.

[16] Habermas, J. (1988). Popular Sovereignty as Procedure. In Bohman, J. \& W. Rehg (eds.), Deliberative Democracy: Essays on Reason and Politics. Cambridge, MA: M.I.T. Press, 35-66.

[17] Habermas, J. (1990). Discourse Ethics: Notes on a Program of Philosophical Justification. In Habermas, J. (ed.), Moral Consciousness and Communicative Action. Cambridge, MA: M.I.T. Press, 43-115.

[18] Habermas, J. (1998). Towards a Critique of the Theory of Meaning. In Cooke, M. (ed.), On the Pragmatics of Communication. Cambridge, MA: M.I.T. Press, 277-306.

[19] Habermas, J. (1999). Between Facts and Norms. Contributions to a Discourse Theory of Law and Democracy. Cambridge, UK: Polity Press.

[20] Habermas, J. (2006). The Divided West. Cambridge, UK: Polity Press.

[21] Habermas, J., C. Cronin, \& P. De Greiff. (1998). The Inclusion of the Other: Studies in Political Theory. Cambridge, MA: M.I.T. Press.

[22] Head, N. (2008). Critical Theory and Its Practices: Habermas, Kosovo and International Relations. Politics 28.3, $150-159$.

[23] Spencer, A. \& R. Hülsse. (2008). The Metaphor of Terror: Terrorism Studies and the Constructivist Turn. Security Dialogue 39.6, 571-592.

[24] Hülsse, R. (2006). Imagine the EU: The Metaphorical Construction of a Supra-Nationalist Identity. Journal of International Relations and Development 9.4, 396-421.

[25] Jayyusi, L. (2012). Terror, War and Disjunctures in the Global Order. In Freedman, D. \& D. K. Thussu (eds.), Media and Terrorism: Global Perspectives. London: Sage Publications, 23-46.

[26] Johnson, R. B. (1997). Examining the Validity Structure of Qualitative Research. Education 118.2, $282-292$.

[27] Johnstone, I. (2004). The Power of Interpretive Communities. In Barnett, M. \& R. Duvall (eds.), Power in Global Governance. New York: Cambridge University Press, 185-204.

[28] Jorgensen, M. \& L. J. Phillips. (2002). Discourse Analysis as Theory and Method. London: Sage Publications.

[29] Jowett, G. \& V. O’Donnell. (1992). Propaganda and Persuasion. Newbury Park: Sage Publications.

[30] Kampf, Z. (2012). From 'There Are No Palestinian people' to 'Sorry for Their Suffering': Israeli Discourse of Recognition of the Palestinians. Journal of Language and Politics 11.3, 427-447.

[31] Laclau, E. \& C. Mouffe. (1985). Hegemony and Socialist Strategy. London, UK: Verso Books.

[32] Lakoff, G. (1992). The Contemporary Theory of Metaphor. In Ortony, A. (ed.), Metaphor and Thought. New York: Cambridge University Press, 202-251.

[33] Lakoff, G. \& P. (1999). Foreign Policy by Metaphor. In Schäffner, C. \& A. Wenden (eds.), Language and Peace. Amsterdam: Ashgate, 37-59.

[34] Lakoff, G. \& M. Johnson. (2003). Metaphors We Live By. London: The University of Chicago Press.

[35] McCarthy, T. A. (1979). The Critical Theory of Jürgen Habermas. Cambridge, MA: M.I.T. Press.

[36] McClintock, E. \& T. Nahimana. (2008). Managing the Tension between Inclusionary and Exclusionary Processes: Building Peace in Burundi. International Negotiation 13.1, 73-91.

[37] Mio, J. S., R. E. Riggio, S. Levin \& R. Reese. (2005). Presidential Leadership and Charisma: The Effects of Metaphor. Leadership Quarterly 16.2, 287-294.

[38] Mishal, S. \& A. Sela. (2006). The Palestinian Hamas. New York: Columbia University Press.

[39] Mitzen, J. (2006). Ontological Security in World Politics: State Identity and the Security Dilemma. European Journal of International Relations 12.3, 341-370. 
[40] Mouffe, C. (2000). Deliberative Democracy or Agonistic Pluralism? IHS Political Science Series Working Paper 72.

[41] Mouffe, C. (2005). On the Political. New York: Routledge.

[42] Mullin, C. (2010). Islamist Challenges to the 'Liberal Peace' Discourse: The Case of Hamas and the Israel—Palestine 'Peace Process'. Millennium - Journal of International Studies 39.2, 525-546.

[43] Pasquali, G. (2012). The Role of Hamas in the Israeli Discourse: From Discourse Ethics to Cognitive Linguistics. Saarbrueken: LAP Lambert.

[44] Ruitenberg, C. W. (2009). Educating Political Adversaries: Chantal Mouffe and Radical Democratic Citizenship Education. Studies in Philosophy and Education 28.3, 269-281.

[45] Schanzer, J. (2008). Hamas vs. Fatah. The Struggle for Palestine. New York: Palgrave MacMillan.

[46] Shamir, B., E. Zakay, E. Breinin \& M. Popper. (1998). Correlates of Charismatic Leader Behavior in Military Units: Subordinates' Attitudes, Unit Characteristics, and Superiors' Appraisals of Leader Performance. Academy of Management Journal 41.4, 387-409.

[47] Spencer, A. (2011). Bild Dir Deine Meinung: Die Soziale Konstruktion von Terrorismus in Den Medien. Zeitschrift für Internationale Beziehungen 18.1, 1-25.

[48] Stein, J. G. (2001). Image, Identity, and the Resolution of Violent Conflict. In Crocker, C.A., F. O. Hampson \& P. Aall (eds.), Turbulent Peace: The Challenges of Managing International Conflict. Washington D.C.: United States Institute of Peace Press, 189-208.

[49] Toomey, M. \& B. Singleton. (2014). The Post-9/11 'Terrorism' Discourse and Its Impact on Nonstate Actors: A Comparative Study of the LTTE and Hamas. Asian Politics and Policy 6.2,183-98.

[50] Torfing, J. (1999). New Theories of Discourse: Laclau, Mouffe and Ziszek. Oxford, UK: Wiley-Blackwell.

[51] Turner, M. (2009). The Power of 'Shock and Awe': The Palestinian Authority and the Road to Reform. International Peacekeeping 16.4, 562-577.

[52] Wanis-St John, A. \& D. Kew. (2008). Civil Society and Peace Negotiations: Confronting Exclusion Introduction: Inclusion and Exclusion in Peace Negotiations. International Negotiation 13.1, 11-36.

[53] Wehrenfennig, D. (2008). Conflict Management and Communicative Action: Second-Track Diplomacy from a Habermasian Perspective. Communication Theory 18.3, 356-375.

[54] Wodak, R. \& M. Reisigl. (2009). The Discourse-Historical Approach (DHA). In Wodak, R. M. (ed.), Methods of Critical Discourse Analysis. London, UK: SAGE Publications, 87-119.

[55] Worsham, L. \& G. A. Olson. (1999). Rethinking Political Community: Chantal Mouffe's Liberal Socialism. JAC 19.1, 166201.

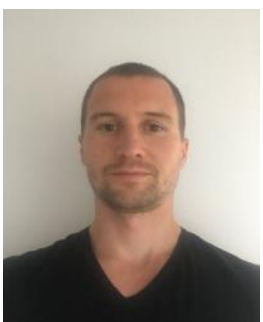

Giovanni Pasquali holds a PhD in International Development from the University of Oxford, 2018. He further earned an MSc in Global Governance and Diplomacy at the University of Oxford in 2012, and an MA in International Relations at the Jacobs University Bremen (Bremen, Germany) in 2011.

He presently works as a Research Associate at Global Development Institute, University of Manchester, in the UK. Over the last three years, he worked as a Short-term Consultant for the World Bank, UN Environment, and the University of Oxford Technology \& Management Centre for Development. He is the author of a number of journal articles, including: 'Rethinking the Governance of Labour Standards in SouthSouth Regional Value Chains', Global Networks, 2019; and 'The Role of Diplomatic Culture in International Disputes', Peace Review, 2014. Currently, his research focuses on the public and private governance of Global Value Chains, with particular interest on aspects related to innovation and upgrading in small and medium enterprises in Eastern and Southern Africa. 